\title{
Financial Soundness of Insurtech Companies in India - An Analysis
}

\author{
P. Kalyani ${ }^{1} \&$ Disha Pathak ${ }^{2}$ \\ ${ }^{1}$ Assistant Professor, Amity Global Business School - Hyderabad, India \\ Orcid ID: 0000-0001-5335-6762; E-mail: pola.kalyani@gmail.com \\ ${ }^{2}$ Assistant Professor, Amity Global Business School - Hyderabad, India \\ Orcid ID: 0000-0002-9018-9403; Email: dishame7@gmail.com
}

Area of the Paper: Business Management.

Type of the Paper: Research Case Study.

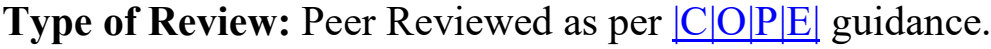

Indexed In: OpenAIRE.

DOI: http://doi.org/10.5281/zenodo.4178328

Google Scholar Citation: IJCSBE.

\section{How to Cite this Paper:}

Kalyani P. \& Disha Pathak (2020). Financial Soundness of Insurtech Companies in India An Analysis. International Journal of Case Studies in Business, IT, and Education (IJCSBE), 4(2), 203-211. DOI: http://doi.org/10.5281/zenodo.4178328

International Journal of Case Studies in Business, IT and Education (IJCSBE)

A Refereed International Journal of Srinivas University, India.

(C) With Authors.

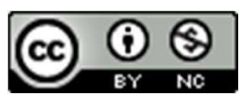

This work is licensed under a Creative Commons Attribution Non-Commercial 4.0 International License subject to proper citation to the publication source of the work.

Disclaimer: The scholarly papers as reviewed and published by the Srinivas Publications (S.P.), India are the views and opinions of their respective authors and are not the views or opinions of the S.P. The S.P. disclaims of any harm or loss caused due to the published content to any party. 


\title{
Financial Soundness of Insurtech Companies in India - An Analysis
}

\author{
P. Kalyani ${ }^{1}$ \& Disha Pathak ${ }^{2}$ \\ ${ }^{1}$ Assistant Professor, Amity Global Business School - Hyderabad, India \\ Orcid ID: 0000-0001-5335-6762; E-mail:pola.kalyani@gmail.com \\ ${ }^{2}$ Assistant Professor, Amity Global Business School - Hyderabad, India \\ Orcid ID: 0000-0002-9018-9403; Email: dishame7@gmail.com
}

\begin{abstract}
Insurtech is the latest buzz word that is shaking up the insurance world globally. In the simplest terms, insurtech can be defined as insurance coupled with technology. Though insurtech is still believed to be in nascent stages in India, the insurtech start-ups in India are changing the market dynamics to a great extent. The present study aims to analyse the financial soundness of insurtech companies in India and also to compare the financial soundness of these two companies. Two leading insurtech companies namely, Go digit and Acko are taken as sample of the study. The financial data pertaining to these two companies for a period of three years from 2017-18 to 2019-20 was used for the analysis. The financial indicators of CARAMELS model were used for analysing the financial soundness of these companies. Six parameters of the CARAMELS model namely C - Capital adequacy, A - Asset quality, RA - Reinsurance and Actuarial issues, M - Management soundness, E - Earnings and profitability and L - Liquidity were used for the purpose of analysis. Through the results of the study, it was found that the financial soundness of Go digit was better than Acko as in four out of six parameters i.e. capital adequacy, reinsurance and actuarial issues, management soundness and earnings \& profitability, it has exhibited better performance. Further only in terms of Asset quality and liquidity Acko was performing better.
\end{abstract}

Keywords: Insurtech, CARAMELS Model, Go Digit, Acko, Financial Soundness

\section{INTRODUCTION:}

Over the last decade, there was a sea through change in the landscape of insurance across the world. Insurtech is the latest buzz word that is shaking up the insurance world globally. In the simplest terms insurtech can be defined as insurance coupled with technology. By adding technologies to insurance, insurers are able to change the way they sold their products and served their customers. Leveraging the latest technologies like artificial intelligence, big data, chat bots, smart phone apps etc. the insurtech companies are able to provide simpler and faster products and there by leaving a seamless experience to their buyers. Though insurtech is still believed to be in nascent stages in India, in the last three years, there was a gradual growth in the number of digital players in both life and non- life insurance sectors. Many fully digital insurance intermediaries have also sprung up in the recent times in India. The emergence of insurtech start-up companies like Acko, Toffee insurance, Go digit have started changing the market dynamics in the Indian insurance industry in a big way. The monthly business statements of insurance companies in India which are published by IRDAI [1] reveal an interesting fact about two budding insurtech start-ups in the non-life insurance sector namely Go digit and Acko. According to these published statements, both these companies which have a market share of less than $1 \%$ have registered a premium growth of $82 \%$ and $164 \%$ respectively by the end of FY2019-20. This is relatively a very high growth compared to that of large traditional insurance players. Against this backdrop, it is interesting to understand the sustainability of these companies in the long run and also to know whether the business operations of these companies are resulting in positive earnings or not. Hence, the current study has been taken up to conduct a detailed analysis of the financial soundness of these two companies. 


\section{RELATED STUDIES:}

A Review of literature related to financial performance of insurance companies and insurtech in general has been presented below:

Joo (2013) [2] has studied the solvency position of non-life insurers in India by using ISI predictors. Further a multiple regression analysis was conducted to identify various determinants of solvency of Indian non-life insurers. He found that firm size and claims ratio have a significant impact on solvency position of non-life insurers. Dey, Adhikari and Bardhan (2015) [3] have examined the various determinants of financial performance of life insurers in India. They have found that size and underwriting risk have a significant positive relationship with ROE and leverage and volume of capital have a significant negative relationship with ROE of Indian life insurers. By taking the data of eight non-life insurance companies in India, Daare (2016) [4] has studied the factors determining the profitability of non-life insurance companies in India. He found that liquidity, company size and inflation have significant impact on profitability of these selected companies. Chellasamy \& Valarmathi (2017) [5] have analysed the financial soundness of top five non-life insurance companies in India. They also tried to examine the relationship between the various parameters of CARAMEL model. They have found that among the select companies, New India Assurance has exhibited a relatively satisfactory performance in terms of all financial indicators. Pal, Bhattacharjee and Pal (2017) [6] have assessed the future growth potential of non-life insurers in India. They conducted a detailed analysis of underwriting performance of Indian non-life insurers by taking a fifteen-year data from 2000-01 to 2014-15. They have found that there is an underwriting cycle patterns present in the performance of these companies. Stoeckli, Dremel and Uebemickel (2018) [7] have explored the transformational capabilities and characteristics of insurtech innovations in order to understand the value creation of insurance in the digital world. They have developed a model consisting of 14 transformational capabilities and 52 characteristics which explains the firm level value creation as well as role of digital intermediaries in insurance market.

From the review of literature, it was observed that though there are many studies that have used CARAMEL model to analyse the financial performance of Indian insurers, none of them have focused on insurtech companies. The empirical studies related to insurtech have not focused on the financial performance of these companies. Therefore, understanding the growing importance of insurtech across the world and particularly in India, the following study has been taken up.

\section{OBJECTIVES:}

1. To analyse the financial soundness of insurtech companies in India

2. To compare the financial soundness of insurtech companies in India

\section{METHODOLOGY:}

\subsection{Sources of Data}

The study is based on secondary data collected from the published annual reports and public disclosures of insurtech companies in India.

\subsection{Period of Study}

The period of study was 3 years from 2017-18 to 2019-20.

\subsection{Sample}

Two insurtech companies currently operating in the non-life insurance sector of India namely, Go Digit General Insurance Company Ltd and Acko General Insurance Company Ltd. were taken as the sample of the study.

\subsection{Tools and Techniques}

In order to analyse the financial soundness of insurtech companies, following the methodology of Chellasamy \& Valarmathi (2017) [5], Ghimire \& Kumar (2014) [8], Simpson \& Damoah (2008) [9] CARAMELS model was used. Six parameters of the CARAMELS model namely C-Capital adequacy, A - Asset quality, RAReinsurance and Actuarial issues, M- Management soundness, E - Earnings and profitability and L - Liquidity were used for the purpose of analysis. S- Sensitivity to market risk was excluded due to non-availability of data. The various ratios used to analyse these parameters and their measurement is given in table 1. 
Table 1 : Measurement of Financial Indicators

\begin{tabular}{|c|c|c|}
\hline $\begin{array}{l}\text { CARAMEL } \\
\text { Parameters }\end{array}$ & Ratio Used & Formula \\
\hline C - Capital Adequacy & Solvency Ratio & $\begin{array}{l}\text { Available Solvency Margin / } \\
\text { Required Solvency Margin }\end{array}$ \\
\hline A - Asset Quality & $\begin{array}{l}\text { Equities to Total } \\
\text { Assets Ratio }\end{array}$ & Equities / Total Assets \\
\hline $\begin{array}{l}\text { RA - Reinsurance and } \\
\text { Acturial Issues }\end{array}$ & Net Retention Ratio & Net Premium / Gross Premium \\
\hline $\begin{array}{l}\text { M - Management } \\
\text { Soundness }\end{array}$ & $\begin{array}{l}\text { Operating Expenses to } \\
\text { Gross Premium Ratio }\end{array}$ & $\begin{array}{l}\text { Operating Expenses / Gross } \\
\text { Premium Ratio }\end{array}$ \\
\hline $\begin{array}{l}\text { E - Earnings and } \\
\text { Profitability }\end{array}$ & Loss Ratio & $\begin{array}{l}\text { Net Incurred Claims / Net Earned } \\
\text { Premium }\end{array}$ \\
\hline- & Expense Ratio & $\begin{array}{l}\text { (Net Commission + Operating } \\
\text { Expenses) / Net Written Premium }\end{array}$ \\
\hline- & Combined Ratio & Loss ratio + Expense Ratio \\
\hline- & $\begin{array}{l}\text { Investment Income to } \\
\text { Net Premium Ratio }\end{array}$ & $\begin{array}{c}\text { Investment Income / Net Earned } \\
\text { Premium }\end{array}$ \\
\hline- & Return on Equity & Net Profit After Tax / Net worth \\
\hline L - Liquidity & Liquidity Ratio & Liquid Assets / Current Liabilities \\
\hline
\end{tabular}

Source: Own compilation based on review of literature

\section{RESULTS:}

The results and analysis of various parameters of CARAMELS model through various financial indicators has been presented below.

\subsection{Capital Adequacy}

Capital adequacy of a company indicates whether it has sufficient capital to meet its claims. In this study solvency ratio has been chosen to assess the capital adequacy position of the insurtech companies. Solvency ratio assesses the capacity of an insurtech company to meet its short term and long-term debt obligations. Solvency ratio is measured as the ratio of available solvency margin to required solvency margin. In India IRDAI has stipulated that all the insurance companies should maintain a minimum solvency requirement of $150 \%$. A higher solvency ratio indicates better credit worthiness of an insurtech company and vice versa. The solvency ratios of insurtech companies in India (Table 2) indicate that both Go digit and Acko were meeting the minimum solvency requirement of IRDAI. While Go Digit's solvency ratio was higher in 2017-18 and 2018-19, Acko maintained a higher solvency ratio in 2019-20.

Table 2 : Solvency Ratio

\begin{tabular}{|l|r|r|r|}
\hline & 2017 - 18 & 2018 - 19 & 2019 - 20 \\
\hline Go Digit & 5.48 & 2.27 & 3.24 \\
\hline Acko & 2.48 & 1.78 & 4.24 \\
\hline $\begin{array}{l}|r| \\
\text { Source: Published annual reports of Go digit [10] } \\
\text { and Acko [11] }\end{array}$ \\
\hline
\end{tabular}




\subsection{Asset Quality}

This parameter assesses the quality of assets of am insurtech company. As in Jansirani and Muthusamy (2019) [12], equities to total assets ratio was chosen as a proxy to measure asset quality. This ratio explains the proportion of total assets of a company that are funded by its equity capital. Higher this ratio, the better is the asset quality of the company which thereby indicates a sound financial position of the company. On the contrary, a low asset quality is riskier for the company. The equity to total assets ratios of the insurtech companies (Table 3) shows that in case of go digit in the years 2017-18 and 2018-19, the equities are more than total assets but in the year 2019-20 the ratio has fallen to 0.73 . This shows that the equity share capital of the company has decreased. In the case of Acko, the ratio is more than 1 in all the years and more over the ratio has doubled from 2017-18 to 2018-19 with a slight decrease in 2019-20.

Table 3 : Equities to Total Assets Ratio

\begin{tabular}{|l|r|r|r|}
\hline & $\mathbf{2 0 1 7}-\mathbf{~ 1 8}$ & $\mathbf{2 0 1 8}-\mathbf{1 9}$ & $\mathbf{2 0 1 9} \mathbf{- 2 0}$ \\
\hline Go Digit & 1.277 & 1.407 & 0.73 \\
\hline Acko & 1.096 & 2.63 & 2.576 \\
\hline $\begin{array}{l}\text { Source: Published annual reports of Go digit [10] and Acko } \\
{[11]}\end{array}$ \\
\hline
\end{tabular}

\subsection{Reinsurance and Actuarial Issues}

In order to evaluate this parameter, the risk retention ratio is chosen for analysis. Risk retention ratio indicates the proportion of risk that has been retained by the insurtech companies without transferring to the reinsurers. This ratio is measured as the ratio of net premium to gross premium. A higher ratio indicates higher retention by the company and a lower ratio indicates lower retention of risk by the company. In a way this ratio indicates risk bearing capacity of an insurtech company. The risk retention ratio of insurtech companies shows that go digit has a higher ratio than Acko in all the three years of sample period indicating a higher risk bearing capacity of go digit than Acko.

Table 4 : Risk Retention Ratio

\begin{tabular}{|l|r|r|r|}
\hline & $\mathbf{2 0 1 7 - 1 8}$ & $\mathbf{2 0 1 8}-\mathbf{1 9}$ & $\mathbf{2 0 1 9}-\mathbf{2 0}$ \\
\hline Go Digit & $72.50 \%$ & $79.29 \%$ & $69 \%$ \\
\hline Acko & $39.73 \%$ & $69.24 \%$ & $50.82 \%$ \\
\hline $\begin{array}{l}\text { Source: Published annual reports of Go digit [10] and } \\
\text { Acko [11] }\end{array}$
\end{tabular}

\subsection{Management Soundness}

The operating expenses to gross premium ratio have been considered to evaluate the management soundness of insurtech companies. This ratio reflects the operational efficiency of management of the company. A lower operating expense to gross premium ratio is preferred as it indicates lower operational expenses incurred to write the gross premium and vice versa. The operating expenses to gross premium ratio of insurtech companies (table 5) shows that the ratio has decreased from 90.74 in the year $2017-18$ to $42 \%$ in 2019-20 in case of go digit which is nearly $48 \%$ reduction. In case of Acko the ratio was very high in the year $2017-18(1521.68 \%)$ but gradually the company was able to bring it down to $81.11 \%$ by the year $2019-20$.

Table 5 : Operating Expenses to Gross Premium Ratio

\begin{tabular}{|l|r|r|r|}
\hline & $\mathbf{2 0 1 7 - 1 8}$ & $\mathbf{2 0 1 8}-\mathbf{1 9}$ & $\mathbf{2 0 1 9}-\mathbf{2 0}$ \\
\hline Go Digit & $90.74 \%$ & $49.46 \%$ & $42 \%$ \\
\hline Acko & $1521.68 \%$ & $116.18 \%$ & $81.11 \%$ \\
\hline $\begin{array}{l}\text { Source: Published annual reports of Go digit [10] and } \\
\text { Acko [11] }\end{array}$ \\
\hline
\end{tabular}




\subsection{Earnings and Profitability}

The earnings and profitability analysis has been conducted through five different ratios namely, loss ratio, expense ratio, combined ratio, investment income to net premium earned ratio and return on equity. The loss ratio indicates the amount of claims incurred in relation to premium earned. The expenses ratio indicates the amount of commission and operating expenses incurred in relation to premium earned. The combined ratio indicates the underwriting profitability of the company. A lower loss ratio, expenses ratio and combined ratio is always preferred as it exhibits the underwriting efficiency of the company. The loss ratio of the insurtech companies (Table 6) shows that both the companies had lower claims than premium earned. In all the three years the proportion of claims incurred to net earned premium of Acko was lesser than that of Go digit. Coming to expense ratio (Table 7), in case of Go digit, it has decreased from $112.75 \%$ in the year $2017-18$ to $47.76 \%$ in the year 2019-20. In case of Acko the expense ratio was $1640.48 \%$ in $2017-18$ and has come down to $159.60 \%$. However, Go digit has better expense management compared to Acko. The combined ratio of insurtech companies (Table 8) shows that in case of go digit, the ratio was lesser than that of Acko in all the three years.

The investment income to net premium earned ratio indicates the extent of investment income generated by an insurtech companies apart from its premium income. It explains the contribution of investment income in the profitability of a company. A higher ratio indicates a higher proportion of investment income in total earned premiums. The investment income ratio of insurtech companies (Table 9) shows that in the year 2017-18 both the companies had negligible or no investment income. In 2018-19 Go digit's ratio was 5.21\% whereas Acko's ratio was a little higher with $7.46 \%$. However, by $2019-20$ both the companies had a ratio of $10 \%$ and $10.09 \%$ respectively.

Return on equity is the most popular parameter used to measure the overall profitability of a company. As in Bawa and Verma (2017) [13], it was calculated as the ratio of net profits after taxes to net worth. It explains the efficiency of the company's management in utilising the shareholders' funds i.e., how much profit it is generating out of these funds. A higher ROE tells us that the management was able to generate more return on shareholder's funds and vice versa. The return on equity of insurtech companies (Table 10) shows that both the companies were experiencing losses in all the three years of study period. The year 2018-19 marked highest losses for both the companies. However, by 2019-20 go digit was able to reduce its proportion of losses by $72 \%$ while Acko could reduce it by $41 \%$.

Table 6 : Loss Ratio

\begin{tabular}{|l|r|r|r|}
\hline & $\mathbf{2 0 1 7}-\mathbf{1 8}$ & $\mathbf{2 0 1 8}$ - 19 & $\mathbf{2 0 1 9} \mathbf{- 2 0}$ \\
\hline Go Digit & $93.95 \%$ & $78.83 \%$ & $75 \%$ \\
\hline Acko & $76.70 \%$ & $58.61 \%$ & $60.33 \%$ \\
\hline $\begin{array}{l}\text { Source: Published annual reports of Go digit [10] } \\
\text { and Acko [11] }\end{array}$
\end{tabular}

Table 7 : Expense Ratio

\begin{tabular}{|l|r|r|r|}
\hline & $\mathbf{2 0 1 7}$ - 18 & 2018 - 19 & $\mathbf{2 0 1 9}$ - 20 \\
\hline Go Digit & $112.75 \%$ & $46.32 \%$ & $47.76 \%$ \\
\hline Acko & $1640.48 \%$ & $167.78 \%$ & $159.60 \%$ \\
\hline $\begin{array}{l}\text { Source: Published annual reports of Go digit [10] } \\
\text { and Acko [11] }\end{array}$
\end{tabular}

Table 8 : Combined Ratio

\begin{tabular}{|l|r|r|r|}
\hline & $\mathbf{2 0 1 7}$ - 18 & $\mathbf{2 0 1 8}$ - 19 & $\mathbf{2 0 1 9}$ - 20 \\
\hline Go Digit & $204.97 \%$ & $123.90 \%$ & $117 \%$ \\
\hline Acko & $1717.18 \%$ & $222.50 \%$ & $209.80 \%$ \\
\hline
\end{tabular}

Source: Published annual reports of Go digit [10] and Acko [11] 
Table 9 : Investment Income to Net Premium Ratio

\begin{tabular}{|c|c|c|c|}
\hline & $2017-18$ & $2018-19$ & $2019-20$ \\
\hline Go Digit & Nil & $5.21 \%$ & $10 \%$ \\
\hline Acko & Nil & $7.46 \%$ & $10.09 \%$ \\
\hline \multicolumn{4}{|c|}{$\begin{array}{l}\text { Source: Published annual reports of Go digit [10] } \\
\text { and Acko [11] }\end{array}$} \\
\hline \multicolumn{4}{|c|}{ Table 10 : Return on Equity } \\
\hline & $2017-18$ & $2018-19$ & $2019-20$ \\
\hline Go Digit & $-25.63 \%$ & $-56.46 \%$ & $-16 \%$ \\
\hline Acko & $-9.51 \%$ & $-149.87 \%$ & $-88.63 \%$ \\
\hline $\begin{array}{l}\text { Source: } \mathrm{F} \\
\text { and Acko }\end{array}$ & $\begin{array}{l}\text { lished ann } \\
11]\end{array}$ & 1 reports of $C$ & o digit $[10]$ \\
\hline
\end{tabular}

\subsection{Liquidity}

The liquidity analysis was conducted through liquidity ratio. The liquidity ratio explains the capacity of a company to meet its short-term debt obligations. A liquidity ratio of $1: 1$ is considered to be ideal for any company. The liquidity ratios of insurtech companies (Table 11) shows that the liquidity position of go digit was always lower than that of Acko. The liquidity ratio of go digit has fallen from 0.56 to 0.20 in 2019-10 whereas the liquidity ratio of Acko has fallen from 0.85 to 0.40 in 2019-20.

Table 11 : Liquidity Ratio

\begin{tabular}{|l|r|r|r|}
\hline & $\mathbf{2 0 1 7} \mathbf{- 1 8}$ & $\mathbf{2 0 1 8}$ - 19 & $\mathbf{2 0 1 9}$ - 20 \\
\hline Go Digit & 0.56 & 0.52 & 0.20 \\
\hline Acko & 0.85 & 0.97 & 0.40 \\
\hline $\begin{array}{l}\text { Source: Published annual reports of Go digit [10] } \\
\text { and Acko [11] }\end{array}$ \\
\hline
\end{tabular}

\section{DISCUSSION AND FINDINGS:}

- It was found that both the insurtech companies has met the minimum solvency requirement of $150 \%$ set by the regulator. The insurtech companies have maintained highly adequate capital as they maintain a much higher solvency margin in all the three years than the minimum requirement.

- The asset quality of go digit was found to have fallen in the year 2019-20. Further the asset quality of Acko was better than Go digit in all the three years.

- It was found that the average risk retention ratio of Go digit was $76 \%$ while that of Acko was $53 \%$. This clearly indicates a better risk bearing capacity of Go digit compared to Acko.

- During all the three years from 2017-18 to 2019-20 it was found that Go digit's management soundness was effective when compared to Acko.

- Through the analysis of earnings and profitability it was found that in spite of relatively higher claims incurred, Go digit had a lower combined ratio in all the years. This was mainly possible due to the lower commission and operating expenses of go digit.

- An observable difference was not found between both the companies in terms of investment income ratio. By the year 2019-20 both the companies had an investment income ratio of around $10 \%$.

- It was found that the return on investment of Acko was much lower than that of Go digit in the years 201819 and 2019-20. However, both the companies registered negative returns in all the three years.

- It was found that the average liquidity ratio of Go digit was 0.43 and that of Acko was 0.74 . This shows that the liquidity position of Go digit was less than half of Acko. 


\section{CONCLUSION :}

The current study has analysed the financial soundness of insurtech companies in India. Six parameters of CARAMELS model excluding sensitivity to market risk have been assessed through various financial indicators. The data pertaining to two insurtech companies for a period of three years from 2017-18 to 201920 was considered for the study. The results of the data analysis have shown that in terms of capital adequacy, Go digit has exhibited better performance than Acko. The assets quality of Acko has improved from 2017-18 to 2019-20 whereas in case of Go digit the asset quality has decreased over the three years. An assessment of reinsurance and actuarial issues has shown that Go digit has higher risk bearing capacity with higher retention levels compared to Acko. Even in terms of management soundness Go digit has exhibited better management control in terms of operating expenses than Acko. An assessment of earnings and profitability indicators shows that Go digit has performed well in terms of underwriting profitability and overall profitability. Investment income performance was same in the case of both the companies. In terms of liquidity Go digit has registered lower ratios than Acko. Finally, it can be concluded that the financial soundness of Go digit was better than Acko as in four out of six parameters i.e. capital adequacy, reinsurance and actuarial issues, management soundness and earnings and profitability, it has exhibited better performance than Acko. Only in terms of Asset quality and liquidity Acko was performing better. However, besides the relative performance, both the companies should focus on improving their underwriting efficiency particularly in terms of loss ratio. Partnering of insurtech companies and traditional insurance companies would be the recommended model which would be a win - win situation for both in future.

\section{REFERENCES:}

[1] https://www.irdai.gov.in/ADMINCMS/cms/frmGeneral_List.aspx?DF=MBFN\&mid=3.2.8 referred on $24 / 10 / 2020$.

[2] Joo, B. A. (2013). Analysis of Financial Stability of Indian Non Life Insurance Companies. Asian Journal of Finance \& Accounting, 5(1), 306-319. DOI: http://doi.org//10.5296/ajfa.v5i1.3366.

[3] Dey, N. B., Adhikari, K., \& Bardhan, M. R. (2015). Factors Determining Financial Performance of Life insurance companies of India-An Empirical Study. ERPA International Journal of Economic and Business Review, 3(8), 42-48.

[4] https://eprawisdom.com/jpanel/upload/articles/1059pm8.Prof.\%20Nikhil\%20Bhusan\%20Dey\%20,\%20 Dr.\%20\%20Kingshuk\%20Adhikari\%20\&\%20Mihir\%20Ranjan\%20Bardhan.pdf referred on 25/09/2020.

[5] Daare, W. J. (2016). Determinants of Non-Life insurance companies' profitability: an empirical study in India. International Journal of Innovative Research and Advanced Studies, 3(13), 6-11.

[6] Chellasamy, P. \& Valarmathi, P. (2017). Financial Performance of Select General Insurance Companies in India using CARAMEL Model. EPRA International Journal of Multidisciplinary Research, 3(3), 204210.

[7] https://eprajournals.com/jpanel/upload/734pm 31.P.\%20VALARMATHI\%20-1096.pdf referred on $01 / 10 / 2020$.

[8] Pal, S., Bhattacharjee, K., \& Pal, S. (2017). Forecasting performance of Indian non-life insurance industry-an analysis of underwriting experience of public and private insurance companies. Asian
Journal
of Empirical
Research, 7(1),
$10-18$.

DOI: http://doi.org//10.18488/journal.1007/2017.7.1/1007.1.10.18

[9] Stoeckli, E., Dremel, C., \& Uebernickel, F. (2018). Exploring characteristics and transformational capabilities of InsurTech innovations to understand insurance value creation in a digital world. Electronic Markets, 28(3), 287-305. DOI: http://doi.org//10.1007/s12525-018-0304-7.

[10] Ghimire, R., \& Kumar, P. (2014). Testing of Financial Performance of Nepalese Life Insurance Companies by CARAMELS Parameters. Journal of Business and Management. https://ssrn.com/abstract $=2436682$ referred on 01/10/2020.

[11] Simpson, S. N. Y., \& Damoah, O. B. O. (2008). An evaluation of financial health of non-life insurance companies from developing countries: The case of Ghana. 21st Australasian Finance and Banking Conference. DOI: http://dx.doi.org/10.2139/ssrn.1138338

[12] https://www.godigit.com/financials referred on 05/10/2020.

[13] https://www.acko.com/annual-reports/ referred on 05/10/2020. 
[14] Jansirani, P., \& Muthusamy, A. (2019). Caramel analysis of financial efficiency of public sector Non-life insurance companies in India. ZENITH International Journal of Business Economics \& Management Research, 9(6), 16-34. Retrieved from https://www.zenithresearch.org.in

[15] Bawa, S. K., \& Verma, N. (2017). Conducting Financial Analysis of the Indian Reinsurer-GIC Re. Pacific Business Review International, 10(3), 113-120.

[16] http://www.pbr.co.in/2017/sepThirteen.aspx referred on 27/09/2020.

$* * * * * * * * * * *$ 